\title{
コンファレンスレポート
}

\section{CLEO/IQEC'86報告 III}

—レーザー同位体分離・レーザー化学——

\section{仁木秀明 ${ }^{*} \cdot$ 山 中龍彦 ${ }^{*} \cdot$ 小林孝嘉}

\author{
Report on CLEO/IQEC '86 III \\ - Laser Isotope Separation and Laser Chemistry
}

Hideaki NIKI, Tatsuhiko YAMANAKA* and Takayoshi KOBAYASHI**

高い時間・空間・スペクトル分解能をもつレ ーザー, CARS 技術の進歩, エキシマーレー ザーの実用化により化学反応過程の研究, 選択 的化学反応や同位体分離の研究がここ数年急速 な進展を遂げている。レーザー化学反応に関し ては, 我国では文部省科学研究費補助金で特定 研究として取り上げられると共に半導体分野で は従来の熱化学反応による半導体の処理に代る 方法としてレーザープロセス法の研究が活発に 行なわれている。またレーザー法ウラン濃縮が トリガーとなり光化学反応を利用した同位体分 離の研究が各所で行なわれるようになって来た。

ここではレーザー同位体分離およびレーザー 化学に関する報告の概要について記す。

\section{1.レーザー同位体分離}

レーザー同位体分離関係の発表はUranium and Zirconium Isotope Separation, Laser Chemistry ならびに Copper Vapor Laser, Liquid Laser のセッションで報告された。 レーザー同位体分離のセッション C CLEO
TUI) では, ウラン関係 3 件（米 2 件，西独 1 件）とジルコニウム 1 件 (米)の講演があった。 LLNLからは原子法によるウラン濃縮装置の 現状報告があった。主にレーザー装置のカラー 写真を中心とした講演で, 目新しい内容はなか つたが，大規模な銅蒸気レーザーシステムと それを励起光源とした色素レーザーシステムお よび分離チェンバーにはあらためて迫力を感じ た。銅蒸気レーザー, 色素レーザーの最終段の ビーム径はそれぞれ $80 \mathrm{~mm}^{\Phi}$, 数 $\mathrm{mm}^{\Phi} て ゙ あ り$, 効 率はそれぞれ〜1\%， ～50\%である。レーザー 全システムの寿命は約 100時間であるが，不良 部分はコンポーネントのパッケージを交換する ことにより簡単に復帰できる。レーザー制御は コンピュータによる中央制御方式である。

Uranit GmbH（西独）からは分子法に関す る報告があった。超音速ノズルにより冷却した $\mathrm{UF}_{6}$ ガスに $16 \mu \mathrm{m}$ 光を照射し分離する方式で ある。チューナブル高出力 $16 \mu \mathrm{m}$ 光はTEA $\mathrm{CO}_{2}$ レーザー, 高気圧チューナブルレーザーを水 素ラマンセルに導入し，4 波混合法により発生

* 大阪大学レーザー核融合研究センター（†565 吹田市山田丘 2-6)

**東京大学理学部 ( 1113 東京都文京区本郷 7-3-1)

* Institute of Laser Engineering, Osaka University Yamada-Oka, Suita, Osaka 565)

**Faculty of Science, University of Tokyo (Hongo, Bunkyo-ku, Tokyo 113) 
させる方法を採用している（理研と同方式）。 繰返し周波数 $10 \mathrm{~Hz}$, 出力 $100-200 \mathrm{~mJ}$ （波長 固定光), 8-10 $\mathrm{mJ}$ （波長可変光）を得てい る。レーザーの目標值としては15.8〜 $16.5 \mu \mathrm{m}$ 領域の 3 波長で, スペクトル幅 $\Delta \lambda / \lambda<10^{-4}$, パルス幅 $1 \sim 100 \mathrm{~ns}, 0.5 \sim 1 \mathrm{~J} /$ パルス, 平均 出力 $10 \mathrm{~kW}$ 以上, 繰返し 25 $50 \mathrm{kHz}$ を設定し ている。現在, 幅 $5 \mathrm{~cm}$ のズルを 5 個シリーズ につないだ $25 \mathrm{~cm} の ノ ス ゙ ル て ゙ ~ U F_{6}$ を冷却し選択 解離の実験を行なっている。

Laser Chemistryのセッションで, Isotope Technology (米) から, $\mathrm{UF}_{6}$ と $\mathrm{HCl}$ の混合 ガスをレーザー共振器内のセル内に流して発振 レーザー光により化学反応が促進されることを 利用するウラン濃縮法が提案された。光源として $\mathrm{CO} レ$ ザー ( $5 \mu \mathrm{m})$ を用い, $\mathrm{UF}_{6}$ の $3 \nu_{3}$ 振動準位を励起し, $\mathrm{UF}_{6}{ }^{*}+\mathrm{HCl} \rightarrow \mathrm{UF}_{5} \mathrm{Cl}+$ $\mathrm{HF}$ の反応を促進する方式で, 実 験により, 室温におけるレーザー非照射時の反応速度に比 ベ，レーザー照射時には 6 倍の反応速度が得ら れ, 濃縮も確認されている。この方法によると, 現在主流である原子法や分子法よりも分離コ ストが大幅に低減できるということである。

ウラン以外の報告として, Westinghouse Research \&-Development Center (米) か ら可視光と紫外光を用いたジルコニウムの同位 体分離の報告があった。これは質量数が奇数の ${ }^{91} Z_{\mathrm{r}}$ が核磁気モーメントを持ち, これにより光 化学反応が促進されることを利用して deplete する方法を実験的に示した。これは，原子炉材 料として使用する。実験では1.05 の濃縮比を 得ている。

その他, 別のセッション (CLEO MG) で, ${ }^{124} \mathrm{Te}$ を濃縮した後, 陽子ビーム照射により核 医学用の ${ }^{123} \mathrm{I}$ を生成する方式の提案が（Max Planck Inst. biophysikalische Chemie (西 独））より報告された。トリチウム（T）の濃 縮に関しては理研とカナダの Ontario Hydro より報告があった。Ontario Hydro は昨年の CLEO' 85 で導波管方式を提案したが, この 方式で濃縮を行なう時の導波管径と入射レーザ
一光径関係, レーザー光強度の最適值等の実験 結果について報告した。

原子法ウラン濃縮用の銅蒸気レーザーに関し ては 6 件の発表 (CLEO WE) があり, 内 2 件 (LLNL (米), Oxford Lasers, Ltd. (英)）は発振器のビーム拡がりをinjection locking 法を用いて改善するという内容であっ た。これは, ビームの長距離伝播の際に損失を 低減したり，集光状態を改善するために必要で ある。通常, 銅蒸気レーザーは利得が大きく利 得持続時間が $50 \mathrm{~ns}$ 前後と短かいため round trip 回数が少なく不安定共振器を用いても, ビーム拡がりが小さくならない。 LLNLの実 験結果では発振出力 $20 W(510 \mathrm{~nm})$ の不安定共 振器について, ビーム拡がり $13 \times(2.44 \lambda / D)$ 以下の出力成分が30\%であるのに対し, injection locking を行うことにより 95\%まで改善さ れている。

色素レーザーのセッション（CLEO THI）は 6 件の講演があり, ここでは LANL (米), LLNL (米) の 2 件について述べる。

LANL では100 W/500 Hzの色素レーザー を構築中である。これは Lambda Physik 社 のXeClレーザー (100 W/250 Hz) 14台を励 起光源とした大型システム（発振器 1 台, pre amp 1 台, power amp 3 台) で380-410 nm の発振波長領域をもつ。現在 $250 \mathrm{~Hz}$ で稼動中 であり，28\%の効率を得ている。

LLNL からはウラン原子励起用の色素レー ザーシステムの発振波長の安定化についての講 演があった。発振器は回折格子, プリズムエク スパンダー, エタロンを用いた Hänsch 型共振 器であり，銅蒸気レーザー励起により単一縦モ 一ド発振を得ている。波長の安定化の手法とし ては, 短時間的には, 出力光の一部を温度安定 化されたFabry-Perot エタロンによりモニタ 一し, 発振器の回折格子, エタロン, 出力ミラー をフィードバック制御する方式であり，長時間的 には, 出力モ二ター用のFabry-Perotエタロンを フィゾー型ウェーブメータによりさらにフィード バック制御している。（仁木秀明, 山中龍彦) 


\section{2.レーザー化学}

Laser Chemistry に関係するセッションは 6 月 9 日（月）の MC, Fundamental Chemistry, および MG, Material Production and Modification, と6月10日 (火)のTu D, Diagnostic Laser Chemistry および TuE, Mechanism of Laser Chemical Engineering の 4 つである。その他にポスターセッショ ンにもいくつかの発表があった。それらの発表 の中で主だったものを中心に簡単に説明する。

まずMC, Fundamental Chemistryでは (講演者の都合により， TuCの発表と日時が入 れ換えられたが) 西独 Heidelberg 大学物理化 学研究所のWolfrumが招待講演を行った。その 中で層流や乱流中の化学反応中の化学反応素過 程研究について三つの物を挙げた。この第一の 例は $\mathrm{H}+\mathrm{O}_{2}$ や $\mathrm{H}+\mathrm{CO}_{2}, \mathrm{H}+\mathrm{H}_{2} \mathrm{O}$ などの基礎 的な燃焼反応機構の並進運動の選択励起による 影響についての実験結果を示した。さらに, ab initio 法によるポテンシャル面の計算結果と比 較した。第二の例は層状逆行拡散炎のような定 常流中の化学反応である。

このような化学反応の一例として, 大気圧の メタン/空気逆流拡散炎の中の温度分布が CARS で調べられた。 $2000 \mathrm{~K}$ までの高温の炉 で熱電対と CARS 測定の対比を行ない, 次に こうして得られた $\mathrm{N}$ を分子の CARS スペクト ルの温度依存性をシミューレーションプログラ ムによって評価した。両者の方法で得られた温 度は全温度領域で $40 \mathrm{~K}$ 以内であった。

第三の例として最も複雑な非定常の場合を取 り上げた。即ち彼は閉じた容器の中での均一混 合気体の反応開始と発火の詳細な記述をするた めには, 質量, 運動量, エネルギー, 各々の化 学種の質量分率等の保存則を与える方程式を解 くことを考えた。このように簡単な混合気体系 について燃焼の化学反応の開始過程をシュレー トすることができた。

ニューヨーク州立大学の電子工学科の Mukharjee 等 $(\mathrm{MC} 2)$ は, $\mathrm{C}_{2} \mathrm{~F}_{5} \mathrm{Cl}$ と $\mathrm{SP}_{4}$ の 2
種類の分子についてポンプ（80 ns の $\mathrm{CO}_{2}$ レー ザー）・プローブ（80 ns あるいは $62 \mathrm{ps} の$ $\mathrm{CO}_{2}$ レーザー）法によって振動的にホットな分 子の925-955 cm-1 領域の吸収スペクトルを測 定した結果を報告した。いずれの分子の場合に もピコ秒パルスを用いて測定した衝突のない場 合の吸収スペクトルは $3 \mathrm{~cm}^{-1}$ 程赤方シフトし, スペクトル幅は $4-7 \mathrm{~cm}^{-1}$ 広がった。この結果 をベンゼンのホットバンドに用いられたと同じ 理論的考察をすることで説明することができた。 東大理学部の小林等 (MC 3 ) は印刷やフォ トリソグラフィーに用いられるアジド $\mathrm{RN}_{3}$ の 光化学反応機構について報告した。アジドは分 解すると電子久之性のため非常に反応性が高い ナイトレン R N （基底状態は三重項状態）にな る。ビスビフェニルアジドやジメチルアミノフ エニルアジド等の光分解過程は考えられる下の 二つの機構のうち一重項機構であることを明ら かにした。項間交差（ISC）

$$
\begin{aligned}
& \mathrm{RN}_{3}\left(\mathrm{~S}_{0}\right) \stackrel{\mathrm{h} \nu}{\longrightarrow} \mathrm{RN}_{3}\left(\mathrm{~S}_{1}\right) \stackrel{\substack{\text { 項間交差 } \\
(\mathrm{ISC})}}{\longrightarrow} \mathrm{RN}_{3}\left(\mathrm{~T}_{1}\right) \\
& \stackrel{-\mathrm{N}_{2}}{\longrightarrow} \mathrm{RN}\left(\mathrm{T}_{0}\right) \quad \text { (三重項機構) } \\
& \mathrm{RN}_{3}\left(\mathrm{~S}_{0}\right) \stackrel{\mathrm{h} \nu}{\longrightarrow} \mathrm{RN}_{3}\left(\mathrm{~S}_{1}\right) \stackrel{-\mathrm{N}_{2}}{\longrightarrow} \mathrm{RN}\left(\mathrm{S}_{1}\right) \\
& \stackrel{\text { ISC }}{\longrightarrow} \mathrm{RN}\left(\mathrm{T}_{0}\right) \quad \text { (一重項機構) }
\end{aligned}
$$

であることを明らかにした。電荷移動性が増加 すると ISC の速度が速くなることも示した。

西独の Max Planck 研究所の Kompaのグ ループ（MC4）は MPI 分光により $\mathrm{N}_{2}\left(\mathrm{a}^{\prime} \pi \mathrm{g}\right)$ から $\mathrm{CO}\left(\mathrm{A}^{\prime} \pi\right)$ へのエネルギー移動を報告した。 $\mathrm{N}_{2}\left(\mathrm{a}^{\prime} \pi \mathrm{g}, \quad v=2\right)$ から $\mathrm{CO}\left(\mathrm{A}^{\prime} \pi, v\right)$ への衝突 によるエネルギー移動の後 $\mathrm{h} \nu_{2}$ でCO 分子内の 回転準位を分解した A $\rightarrow \mathrm{B}$ 遷移をひきおこさせ， さらに $\mathrm{h} \nu_{1}$ でイオン化させることにより COO 回転準位へVのエネルギー移動の分岐比が求め られる。

$$
\mathrm{CO}\left(\mathrm{A}^{\prime} \pi, v\right) \stackrel{\mathrm{h} \nu_{2}}{\longrightarrow} \mathrm{CO}\left(\mathrm{B}^{\prime} \Sigma^{+}, v^{\prime}\right) \stackrel{\mathrm{h} \nu_{1}}{\longrightarrow} \mathrm{CO}^{+}
$$

このようにして $v=0,1,2,3,4,5$ に対し分岐比 $0.24,0.05,0.28,11,0.05,0.27$ が求め られた。 
米国 Dow Chemical の Knudsen (MG2) は レーザーによる超微細セラミックス粉末の製法 について報告した。100 $\mathrm{W} の \mathrm{CO}_{2}$ レーザーを $\mathrm{H}_{2}$ と $\mathrm{BCl}_{3}$ の混合気体に照射することにより $94 \%$ 以上の超高純度アモルファスボロンを $33 \%$ 以上 の効率 $\left(\mathrm{BCl}_{3}\right.$ からの変換の効率） で得ること ができた。反応容器の圧力を変えることにより, 平均径を 220 から $1100 \mathrm{~A}$ の領域に制御するこ とが可能である。この他に $\mathrm{TiB}_{2}$ や $\mathrm{B}_{4} \mathrm{C}$ の粉末 の合成も行ない高純度が確認された。

米国 IBMのDreyfus 等は (TuDl) エキシ マレーザーを用いたレーザーエッチングの機構 をエッチング面から噴出される原子, 分子, イ オン種の色素レーザーによるレーザー誘起螢光 法により研究した。研究された物質は $\mathrm{Al}_{2} \mathrm{O}_{3}$, $\mathrm{Al}: \mathrm{O}_{2}$, および有機高分子化合物である。温度 上昇による蒸発, 光分解, 高速電子・分子によ るスパッタリング微細液滴形成, 脱離等々の工 ッチング機構の中で, 電子エッチングとも呼ば れる弱い結合あるいは解離的結合の状態への遷 移による光分解を支持する実験結果を三つ報告 した。それらは第一に，各々の表面から得られ た $\mathrm{AlO}$ やCN 等の二原子分子の内部エネルギー は< $1000 \mathrm{~K}$ であり, 熱過程が否定される。第二 に $\mathrm{Al}: \mathrm{O}_{2}$ の場合, エッチングの度合は被ふく 度による。即ち, 結合状態による。第三に飛行 時間法で求められた運動エネルギーが熱過程で 期待されるよりも圧倒的に大きいという点であ る。

$$
\text { オーストラリアのニューサウスウェールズ物 }
$$

理学校の K. J. Grant 等(Tu D3) は100 mJ /pulse $の \mathrm{KrF}$ レーザー鉄鉱石に集光し, 25,000 Kのプラズマを発生させ, 鉄イオン,
シリコン, イオン等からの発光を分光し, 化学 分析に用いた。西独マックスブランク研究所の S. Opitz 等は, 単一および二波長励起による $\mathrm{N}_{2}$ ジェットの選択イオン化の波長依存性と共 鳴効果を調べた。単色励起の実験では, $\mathrm{X}(v=$ $0) \stackrel{2 \mathrm{~h} \nu}{\longrightarrow} \mathrm{a}(v=10) \stackrel{\mathrm{h} \nu}{\longrightarrow} \mathrm{N}_{2}^{+}(\mathrm{X}, v)$ と $\mathrm{X}(v=$ $0) \stackrel{2 \mathrm{~h} \nu^{\prime}}{\longrightarrow} \mathrm{a}(v=2,3,4) \stackrel{2 \mathrm{~h} \nu^{\prime}}{\longrightarrow} \mathrm{N}_{2}^{+}(\mathrm{X}, v)$ とを 比較し, 後者の Franck-Condon 因子の大きさ が大きいため効率的であることがわかった。ま た, 二色励起の実験で, $\mathrm{X}(v=0) \stackrel{2 \mathrm{~h} \nu_{1}}{\longrightarrow} \mathrm{a}(v)$ $\stackrel{\mathrm{h} \nu_{2}}{\longrightarrow} \mathrm{Cn}^{\prime}(v)[\mathrm{Cn}(v)] \stackrel{\mathrm{h} \nu_{1} \text { or } \mathrm{h} \nu_{2}}{\longrightarrow} \mathrm{N}_{2}^{+}(\mathrm{X}, v)$ ここ

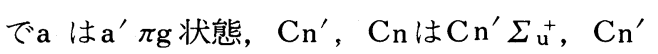
$\pi_{\mathrm{u}}$ リドベルク状態である。

米国 IBMのC. J. Chen（Tu El）は、レーザ 一を励起光源とした場合の光化学 CVD の理論 に関して招待講演した。理論の紹介の他, 文献 にない気相や吸着相における光分解断面積等の 物理量の測定法についても言及した。また，ジ エチル亜鉛のレーザー光化学 CVD を例として, 実験と評論の対比を行ない, 良い一致が見られ ることを示した。同じ IBMのJ. M. Jasinski ( Tu E2) は $\mathrm{TEACO}_{2} レ$ レ゙ーやエキシマレー ザーを用いてシリコンの水素化物（シラン, ジ シラン）を含む物質系の分解, 反応の初期過程 を調べた。その結果, シランからシリレン

$\left(\mathrm{SiH}_{2}\right)$ への分解が $\mathrm{CO}_{2}$ レーザー誘起による CVDの最初の過程であることを明らかにした。 マックスプランク研究所の Lanciprete 等はピ コ秒色素レーザーと飛行時間分解質量分析器と を用いて, $\mathrm{CH}_{3} \mathrm{TeCH}_{3}, \mathrm{CH}_{3} \mathrm{TeTeCH} \mathrm{CH}_{3}, \mathrm{C}_{5} \mathrm{H}^{-}$ $\mathrm{TeC}_{2} \mathrm{H}_{5}, \mathrm{CH}_{3} \mathrm{SeCH}_{3}, \mathrm{CH}_{3} \mathrm{SeSeCH}_{3},\left(\mathrm{CH}_{3}\right)_{3}$ $\mathrm{Ga},\left(\mathrm{CH}_{3}\right)_{3} \mathrm{In}, \mathrm{AsH}_{3}, \mathrm{Tl} \mathrm{BA}$ 等の有機金属化合 物のCVDを行った。

(小林孝嘉) 